\title{
UPAYA GURU DALAM MEMBENTUK KARAKTER TANGGUNG JAWAB SISWA DI ERA PANDEMI COVID-19
}

\author{
${ }^{1}$ Hasna Quin Afdhila, ${ }^{2}$ Fajar Setiawan, ${ }^{3}$ Badruli Martati \\ ${ }^{\mathbf{1 , 2 , 3}}$ Pendidikan Guru Sekolah Dasar, Fakultas Keguruan dan Ilmu Pendidikan, \\ Universitas Muhammadiyah Surabaya \\ E-mail: hasna.quin.afdhila-2017@fkip.um-surabaya.ac.id
}

Received: Nov 4, 2021 Revised: Nov 11, $2021 \quad$ Accepted: Nov 27, 2020

\begin{abstract}
ABSTRAK
Tujuan dari penelitian ini untuk mengetahui upaya guru dalam membentuk karakter tanggung jawab siswa selama pembelajaran daring. Jenis penelitian yang digunakan adalah penelitian yang bersifat deskriptif kualitatif dengan menggunakan teknik pengumpulan data berupa wawancara pada guru wali kelas VI, guru wali kelas V sebelumnya, dan juga kuisioner yang dibagikan ke siswa, serta wali murid SD Muhammadiyah 26 Surabaya. Adapun metode pengumpulan data yang digunakan yaitu wawancara, angket dan dokumentasi. Hasil penelitian ini yaitu upaya guru dalam membentuk karakter tanggung jawab siswa dengan cara berdoa terlebih dahulu sebelum pembelajaran dimulai, memberikan soal yang ada batas waktu mengerjakan sehingga membuat siswa menjadi lebih disiplin, tanggung jawab dalam pengumpulan tugas, pengecekan kelengkapan tugas-tugas, konsekuensi yang diberikan guru untuk siswa yang tidak mengerjakan tugas, tanggung jawab siswa saat masuk dalam pembelajaran online, serta memberikan teguran terhadap siswa yang tidak mengerjakan tugas dengan hasil karya sendiri.
\end{abstract}

Kata Kunci: karakter, tanggung jawab, siswa, SD.

\begin{abstract}
the purpose of this study is to determine the teacher's efforts in shaping the character of student responsibility during online learning. The type of research used is descriptive qualitative research using data collection techniques in the form of interviews with homeroom teachers for class VI, previous homeroom teachers for class V, and also questionnaires distributed to students, as well as guardians of SD Muhammadiyah 26 Surabaya. The data collection methods used are interviews, questionnaires and documentation. The results of this study are the teacher's efforts in shaping the character of student responsibility by praying before learning begins, giving questions that have a time limit for working so that students become more disciplined, responsibility in collecting assignments, checking the completeness of assignments, the consequences given. teachers for students who do not do assignments, students' responsibilities when entering online learning, as well as giving reprimands to students who do not do assignments with their own work.
\end{abstract}

Keywords: character, responsibility, students, elementary school. 


\section{PENDAHULUAN}

Pendidikan adalah salah satu kebutuhan terpenting dalam kehidupan manusia yang dapat membentuk sumber daya manusia berkualitas, baik dari segi fisik, mental maupun operasional, karena pendidikan merupakan lingkup pengembang minat, bakat, dan kemampuan peserta didik secara optimal. Hal tersebut telah tertulis dalam Undang-Undang Republik Indonesia No. 20 Tahun 2003 yang berbunyi: "Pendidikan adalah usaha sadar dan terencana untuk mewujudkan suasana belajar dan proses pembelajaran agar peserta didik secara aktif mengembangkan potensi dirinya untuk memiliki kekuatan spiritual keagamaan, pengendalian diri, kepribadian, kecerdasan, akhlak mulia, serta keterampilan yang diperlukan dirinya, masyarakat, bangsa dan negara.” Berdasarkan Undang-Undang Sistem Pendidikan Nasional diyatakan bahwa Pendidikan Nasional berfungsi untuk mewujudkan suasana belajar dan proses pembelajaran agar peserta didik secara aktif mengembangkan potensi dirinya yang dapat menumbuhkan kekuatan spiritual keagamaan bertaqwa kepada Tuhan Yang Maha Esa, pengendalian diri, kepribadian, kecerdasan, akhlak mulia, serta berguna bagi masyarakat.

Kondisi sekarang ini Negara Indonesia, bahkan seluruh negara di dunia sedang mengalami bencana yang berhubungan dengan kesehatan serta dikenal dengan nama virus covid-19. Covid-19 dapat mengancam kesehatan, perekonomian dan pendidikan masyarakat. Seluruh masyarakat berfokus pada bagaimana cara untuk mengobati atau menghindari covid19. Dalam proses pembelajaran, normalnya terdapat interaksi antara guru dan siswa dan terdapat timbal balik antara guru dan siswa dalam situasi kelas yang kondusif dan edukatif. Pada kenyataannya pendidikan di Indonesia selalu berkembang dengan adanya perubahan dan terdapatnya metode-metode baru dalam pembelajaran dan karena adanya kendala yang disebabkan pandemi Covid-19, proses belajar mengajar dapat dilakukan dengan berbagai aplikasi yang memungkinkan guru dan murid tidak perlu tatap muka secara langsung dalam melaksanakan proses pembelajaran hasil belajar merupakan suatu proses yang dilakukan guru pada akhir kegiatan pembelajaran atau akhir program untuk menentukan angka hasil belajar peserta didik. Adanya covid-19 mengharuskan untuk semua orang agar dapat menjaga jarak sehingga dampaknya dapat dirasakan secara langsung dalam semua sisi kehidupan. Anak usia dini juga menjadi korban efek lingkungan pendidikan, mereka semua diliburkan dan diganti dengan belajar dari rumah (Oktaria, 2020). Pada abad ke-21, dampak dari covid-19 mewajibkan seluruh pembelajaran dilakukan secara daring. Di era pandemi covid-19 seperti ini, peran orang tua menjadi kunci utama dalam pembelajaran anak yang berhubungan dengan minat belajar anak agar tidak menurun 
meskipun proses pembelajaran tidak secara langsung. Orang tua tidakhanya berperan sebagai orang tua saja di rumah, akan tetapi orang tua memiliki peran penting sebagai guru pada lembaga pendidikan. Saat kondisi seperti ini, orang tua banyak memiliki waktu bersama anak-anaknya sehingga anak dapat berkembang melalui pengasuhan yang diberikan orang tuanya. Keterlibatan orang tua menjadi hal penting selama pembelajaran dirumah untuk membantu anak mencapai sebuah prestasi belajar, meningkatkan hubungan sosial, meningkatkan rasa tanggung jawab, serta mengajarkan anak mengenai kesadaran akan minat belajar. Setiap orang tua memiliki cara tersendiri dalam mendidik anak serta masing- masing orang tua memiliki kekurangan dan kelebihan dalam mengasuh anak. Orang tua harus menjadi contoh baik dalam mendidik dan mengajarkan nilai-nilai kehidupan kepada anak saat kondisi saat ini. Perkembangan anak memiliki kebiasaan yang dicontohkan orang tua atau bersama keluarga yang tinggal dalam satu rumah. Karena anak akan menirukan perilaku keluarganya yang menjadi kebiasaan dalam kehidupan sehari-hari.

Namun pada kenyataannya pelaksanaan pendidikan karakter khususnya pada anak tingkat usia sekolah dasar belum tercapai sepenuhnya. Dapat dilihat dari semakin bergesernya nilai-nilai moral yang muncul dalam masyarakat seperti, kurangnya tingkat kesopanan, tidak disiplin, kurang peduli akan kebersihan lingkungan sekitar, kurangnya rasa tanggung jawab, dan bentuk-bentuk kenakalan terhadap teman entah hanya sekedar lelucon atau ikut-ikutan, terkadang anak secara sadar atau tidak mengejek temannya, misalnya memanggil julukan dari nama orang tuanya yang tidak pantas.

Pada dasarnya, pendidikan karakter adalah usaha sadar dan terencana untuk mendidik dan memberdayakan potensi siswa dalam membangun karakter pribadinya sehingga dapat menjadi individu yang bermanfaat bagi diri sendiri dan lingkungannya. Menurut Suprayitno (2020), Pembentukan karakter tersebut harus melalui perencanaan yang baik, pendekatan yang sesuai, metode belajar dan media pembelajaran yang efektif.

Pendidikan karakter diharapkan dapat membentuk generasi muda yang berkualitas dalam berbagai aspek yang dapat memperkecil dan mengurangi penyebab berbagai masalah budaya dan karakter bangsa. Karakter yang harus dibentuk pada diri siswa banyak macamnya, salah satunya tangggung jawab yang merupakan bagian dari nilai karakter yang penting untuk diterapkan pada siswa. Karakter yang bertanggung jawab adalah sikap dimana perilaku seseorang agar mampu melakukan tugas serta kewajiban yang perlu dilakukan terhadap diri sendiri, masyarakat disekitarnya. Adanya tanggung jawab, siswa memiliki beban yang harus diselesaikan terkait masalah yang sedang dialami. Apabila karakter tanggung jawab dapat diterapkan dengan baik oleh siswa pada sekolah dasar, maka 
akan meningkatkan kualitas generasi yang akan datang.

Karakter tanggung jawab memiliki ciri-ciri yaitu: 1). Selalu mencari tugas dan pekerjaan apa yang harus segera diselesaikan, 2). Menyelesaikan tugas tanpa diminta atau disuruh untuk mengerjakannya, 3). Memahami dan menerima konsekuensi dari setiap tindakan yang dilakukan, 4). Berpikir sebelum berbuat, 5). Melakukan pekerjaan sebaik mungkin dengan hasil yang maksimal, 6). Membersihkan atau membereskan segala sesuatu yang digunakan setelah menggunakan sekalipun tanpa ada orang lain yang melihatnya, 7). Selalu berusaha berbuat sebaik mungkin, 8). Terus berbuat dan tidak berhenti sebelum menyelesaikannya, 9). Ikhlas berbuat karena alasan pengabdian kepada Tuhan Yang Maha Esa. (Yaumi, 2014).

Menurut Yunitasari (2020) mengemukakan bahwa indikator tanggung jawab terdiri dari tiga hal, yaitu: 1). Mengumpulkan tugas tepat waktu; 2). Mengikuti kegiatan pembelajaran online; 3). Mengerjakan tugas berdasarkan hasil karya sendiri. Berdasarkan indikator-indikator tersebut maka, penulis menyimpulkan bahwa sikap tanggung jawab belajar dapat dinilai dari ketepatan dalam pengumpulan tugas, baik ketepatan waktu maupun ketepatan pengerjaan tugas berdasarkan petunjuk, mengikuti kegiatan pembelajaran online, serta berani mengemukakan karya sendiri bukan karya orang lain.

Pada saat peneliti melakukan Magang Karya di SD Muhammadiyah 26 Surabaya, peneliti mengamati siswa kelas VI B. Ada beberapa permasalahan yang ditemukan peneliti, diantaranya pada saat pembelajaran dari rumah atau yang biasa disebut pembelajaran daring, ada beberapa siswa dari kelas VI B yaitu kurangnya tanggung jawab siswa pada saat masuk pembelajaran daring, kurangnya tanggung jawab siswa pada saat mengerjakan tugas dari guru, tetapi tugas dari guru masih ada yang dikerjakan oleh orang tuanya tidak hasil karya sendiri, serta masih ada kurangnya tanggung jawab pada siswa yang tidak mengumpulkan tugas tepat waktu.

Hal tersebut perlu mendapatkan perhatian lebih oleh setiap guru, agar setiap siswa mempunyai tanggung jawab lebih sebagaimana seorang siswa semestinya. Maka dari itu, perlu adanya kerjasama bagi seorang guru dan wali murid supaya proses belajar mengajar bisa dilakukan dengan baik. Berdasarkan eksplorasi peneliti, ditemukan beberapa penelitian terdahulu yang berkaitan dengan penelitian ini yaitu penelitian yang dilakukan oleh (1). Rukmana (2020) dalam penelitiannya bahwa Upaya guru dalam membentuk karakter tanggung jawab melalui kegiatan keagamaan pada siswa kelas IV Madrasah Ibtidaiyah Nurul Ihsan Kota Jambi adalah melalui kegiatan rutinitas yakni melaksanakan sholat dhuha berjamaah, sholat dhuhur berjamaah, program tahfiz juz 30, dan program muhadharah. (2). 
Menurut Aslamiah (2015) dalam penelitiannya bahwa dalam membentuk karakter siswa sebaiknya kepala sekolah menerapkan strategi keteladanan, kedisiplinan, kepemimpinan instruksional dan mutu, serta pemberdayaan seluruh warga sekolah. Guru sebaiknya menerapkan strategi keteladanan, pembiasaan, dan sentuhan kalbu. Orang tua dan masyarakat sebaiknya menerapkan strategi komunikasi dan kemitraan efektif. (3). Menurut Pratiwi, dkk (2021) dalam penelitiannya bahwa siswa telah memenuhi empat kriteria sikap tanggung jawab selama pembelajaran daring yang dilakukan di rumah. Adapun empat indicator tersebut, yaitu mengumpulkan tugas tepat waktu, mengerjakan tugas sesuai dengan petunjuk guru, menampilkan hasil berdasarkan hasil karya sendiri, keterlibatan siswa dalam pembelajaran melalui zoom. Tanggung jawab siswa di rumah tidak hanya tanggung jawab belajar saja, akan tetapi juga memiliki tanggung jawab di rumah yakni membantu orang tuanya.

Berdasarkan latar belakang yang telah dijabarkan diatas, maka penulis tertarik untuk melakukan penelitian kepada guru kelas di SD Muhammadiyah 26 Surabaya, dengan tujuan agar dapat mengetahui bagaimana upaya guru dalam membentuk karakter tanggung jawab siswa pada saat pembelajaran daring. Karena pada saat pembelajaran berlangsung di kelas guru lebih mudah untuk mengamati perkembangan karakter siswa secara langsung. Sehingga peneliti mengambil judul “Upaya Guru Dalam Membentuk Karakter Tanggung Jawab Siswa di Era Pandemi Covid-19”

\section{METODE PENELITIAN}

Jenis penelitian yang digunakan adalah penelitian kualitatif deskriptif. Menurut Sugiarto (2015), Penelitian kualitatif adalah jenis penelitian yang temuan-temuannya tidak diperoleh melalui prosedur statistik atau bentuk hitungan lainnya dan bertujuan mengungkapkan gejala secara holistic-kontekstual melalui pengumpulan data dari latar alami dengan memanfaatkan diri peneliti sebagai instrumen kunci.

Metode pengumpulan data yang digunakan penelitian ini yaitu menggunakan teknik pengumpulan data berupa wawancara, angket, dan dokumentasi. Edi (2016) menyebutkan bahwa wawancara merupakan salah satu dari beberapa teknik dalam mengumpulkan informasi atau data. Angket adalah instrumen penelitian yang berisi serangkaian pertanyaan atau pernyataan untuk menjaring data atau informasi yang harus dijawab responden secara bebas sesuai dengan pendapatnya (Arifin, 2012). Dokumentasi adalah catatan peristiwa yang sudah berlalu. Dokumen bisa berbentuk tulisan, gambar, atau karya-karya monumental dari 
seseorang (Sugiyono, 2008). Dokumentasi merupakan metode yang dapat digunakan peneliti untuk mendapatkan data guna menyusun laporan.

Peneliti menggunakan wawancara dan juga angket yang terstruktur sebagai teknik pengumpulan data yang telah menyiapkan instrumen berupa pertanyaan-pertanyaan tertulis. Penelitian ini menggunakan teknik wawancara digunakan untuk mendapatkan data dari narasumber yang dituju yaitu wali kelas VI B, wawancara kepada guru wali kelas V sebelumnya untuk mengetahui siswa pada saat pembelajaran dalam kelas, angket yang di $\begin{array}{llllll}\text { sebarkan } & \text { kepada } & \text { wali } & \text { VI }\end{array}$ https://docs.google.com/forms/d/e/1FAIpQLSf7pyduJ6exHcspFL9DVchHzFOVT6h_i13X0YaHBSoAN1vKA/viewform dan angket kepada seluruh siswa kelas VI B https://docs.google.com/forms/d/e/1FAIpQLSdo_NVJMrmLVSYtKHZ5ExO6RuyskJHE1yc 2p1uwtCyGL1L0KA/viewform.

\section{HASIL DAN PEMBAHASAN}

Pendidikan Karakter merupakan upaya-upaya guru yang dirancang secara sistematis untuk membantu siswa dalam memahami nilai-nilai perilaku manusia yang berhubungan dengan Tuhan Yang Maha Esa, diri sendiri, sesama manusia, lingkungan, dan kebangsaan, kemudian nilai-nilai tersebut dapat terwujud dalam pikiran, sikap, perasaan, perkataan, dan perbuatan berdasarkan norma-norma agama, hukum, tata krama, budaya, dan adat istiadat.

Membentuk karakter siswa tentunya tidak terlepas dari upaya yang dilakukan oleh guru. Berdasarkan hasil penelitian yang telah dilakukan di SD Muhammadiyah 26 Surabaya, bahwasannya upaya yang dilakukan guru dalam membentuk karakter tanggung jawab siswa yaitu melalui kegiatan-kegiatan keseharian saat proses pembelajaran berlangsung selama pembelajaran daring. Menurut Sobron (2019) pembelajaran daring dapat dipahami sebagai pendidikan formal yang diselenggarakan oleh sekolah yang peserta didik dan strukturnya (guru) berada dilokasi terpisah sehingga memerlukan sistem telekomunikasi interaktif untuk menghubungkan keduanya dan berbagai sumber daya yang diperlukan di dalamnya. Pohan, (2020) juga menuturkan bahwa "pembelajaran daring dapat dilakukan dari mana saja dan kapan saja tergantung pada ketersediaan alat pendukung yang digunakan”.

Bentuk kegiatan pembelajaran daring yang diterapkan di SD Muhammadiyah 26 Surabaya dalam membentuk karakter tanggung jawab siswa diantaranya dapat mengumpulkan tugas tepat waktu, mengikuti kegiatan pembelajaran online, serta dapat 
mengerjakan tugas dengan hasil karya sendiri. Temuan penelitian ini menunjukkan bahwa melalui bentuk-bentuk kegiatan pembelajaran daring guru dapat mengembangkan nilai-nilai karakter siswa. Karena peran guru tidak hanya mentransfer ilmu saja, melainkan mendidik siswa agar menjadi manusia yang bertanggung jawab atas segala yang telah diperbuat.

Selain dari upaya yang dilakukan guru dalam membentuk karakter tanggung jawab melalui kegiatan pembelajaran daring, terdapat pula faktor pendukung dan penghambat dalam membentuk karakter tanggung jawab melalui kegiatan pembelajaran daring tersebut. Faktor pendukung dalam membentuk karakter tanggung jawab siswa yaitu adanya sarana prasarana dari orang tua siswa, yakni alat komunikasi handphone yang merupakan pengembangan teknologi telepon yang dari masa ke masa mengalami perkembangan, yang di mana perangkat handphone tersebut dapat digunakan sebagai perangkat mobile atau berpindah-pindah sebagai sarana komunikasi, penyampaian informasi dari suatu pihak ke pihak lainnya menjadi semakin efektif dan efisien. Adapun faktor Penghambat pada saat pembelajaran secara daring yaitu terdapat siswa yang terlambat saat mengumpulkan tugas, terlambat saat masuk ke dalam pembelajaran daring, dan terdapat siswa yang mengerjakan tugas tidak dengan hasil karya sendiri.

Dari beberapa faktor penghambat diatas tentunya ada solusi untuk mengatasi hambatan tersebut. Dari hasil wawancara dan angket dengan wali kelas VI, wali kelas V, siswa, dan orang tua bahwa mengenai solusi dalam penelitian ini sebagai berikut :

\section{A. Wawancara Guru Kelas VI (R.N 37 Tahun)}

Guru memberikan bentuk tugas berupa soal dalam google form, yang dimana siswa diberikan Link soal untuk mengerjakan dengan adanya batas waktu saat mengerjakan, sehingga membuat siswa menjadi lebih disiplin yang membuat mereka termotivasi untuk melihat skor/hasil tugas yang telah dikerjakan. Selama pembelajaran daring dalam kelas VI B terdapat 2 siswa selama pembelajaran online terlambat dalam mengumpulkan tugas, yang 1 siswa tersebut yang mendapatkan perlakuan khusus, sehingga guru harap memaklumi. Upaya guru dalam membentuk karakter tanggung jawab siswa saat ada siswa yang terlambat dalam mengumpulkan tugas yakni setiap pengumpulan tugas guru beri deadline waktu yang telah ditentukan, jadi ketika terlambat disitu akan terlihat dia mengalami keterlambatan, dan sebelumnya telah diadakan peraturan-peraturan apabila ada siswa yang terlambat 
dalam mengumpulkan tugas. Konsekuensi yang diberikan kepada siswa yaitu pengurangan nilai.

Pada saat pembelajaran online dimulai, lalu ada siswa yang terlambat atau tidak hadir, guru langsung menghubungi orang tuanya. Karena, sebelum pembelajaran dimulai, aplikasi Teams dapat calling siswa untuk menyuruh siswa join kalau tidak terhubung, guru langsung menghubungi orang tuanya. Konsekuensi yang guru berikan adalah teguran. Apabila beberapa kali tersebut masih mengulangi kesalahan yang sama, akan saya tanyakan kepada orang tuanya terlebih dahulu sebelum saya berikan konsekuensi tambahan. Selama pembelajaran online, upaya guru dalam membentuk karakter tanggung jawab siswa yakni dengan pembiasaan doa diawal pembelajaran, memfollow up terkait tugas-tugas, monitoring perkembangan tugas dengan pengecekkan kelengkapan tugas.

Selama pembelajaran online guru dapat mengetahui tugas siswa apabila tidak dikerjakan dengan hasil karya sendiri yakni yang pertama dari penulisan, guru mengenali penulisan dengan membandingkan dari tugas-tugas sebelumnya. Yang kedua ketika tugas tersebut deadline pengumpulannya sudah habis guru menghubungi orang tua untuk pengumpulan tugas tersebut. Sehingga, tugas siswa yang belum mengumpulkan akan dikerjakan oleh orang tuanya agar dapat mengumpulkan, yang penting nilainya anak tidak kosong. Meskipun dikerjakan oleh orang tuanya. Upaya guru dalam hal tersebut yakni melakukan teguran kepada siswa secara langsung terkait tugas. Kemudian untuk tugas-tugas selanjutnya guru pantau lebih dari temantemannya, dan selalu diingatkan oleh guru dengan pertanyaan "bagaimana dengan tugasnya? sudah dikerjakan sendiri atau belum?" Selain itu guru juga bekerja sama dengan orang tua, supaya orang tua juga mendidik anaknya untuk lebih bertanggung jawab. Dikarenakan tugas tersebut adalah tugas siswa, bukan tugas orang tua. Konsekuensi yang guru berikan yakni berupa teguran secara pribadi dengan telefon orang tuanya untuk membicarakan. Terkadang ada orang tua yang berinisiatif untuk menelpon guru dan memberitahukan bahwa orang tua yang membantu atau mengerjakan tugas anaknya, dengan alasan yang macam-macam.

\section{B. Wawancara Guru Wali Kelas V (E.D.L 29 Tahun)}

Pada saat kelas VI B duduk di bangku kelas V, terdapat pembelajaran secara offline dan online. Sehingga, terdapat perbedaan permasalahan saat pembelajaran offline maupun online. Sikap siswa saat dulu di bangku kelas V, yakni saat 
pembelajaran offline awal masuk di kelas V, siswa masih tergolong siswa yang ramai dan setelah diadakan peraturan di dalam kelas seperti berdoa, membaca qurán, siswa menjadi lebih baik, tertib, dan saling mengingatkan satu sama yang lain. Saat pembelajaran secara online, karena pada awal pembelajaran secara online dengan menggunakan aplikasi membuat siswa serta orang tua bingung, sehingga siswa menjadi tidak semangat dalam pembelajaran. Pada saat masih duduk di bangku kelas $\mathrm{V}$, siswa memiliki rasa tanggung jawab saat pembelajaran secara offline, salah satu tanggung jawab siswa saat bermain di dalam kelas dengan teman-temannya sehingga sampai merusak fasilitas kelas, setelah itu siswa mempunyai rasa tanggung jawab untuk menggantikan yang baru dengan cara iuran satu kelas. Saat pembelajaran secara online, dapat dilihat dari pengumpulan tugas dengan batasan waktu. Selama pembelajaran secara offline, semua siswa kelas V mengumpulkan tugas tepat waktu, namun pada saat awal pembelajaran online hampir seluruh siswa satu kelas tidak tepat waktu dalam mengumpulkan tugas, guru memaklumi itu. Pada saat berada di bangku kelas $\mathrm{V}$, saat pembelajaran offline, ada beberapa siswa yang memang mengerjakan sendiri tanpa dibantu orang tua, yaitu siswa yang termasuk dalam peringkat 1-10. Setelah itu ada siswa yang memang dibantu dengan orang tuanya, ataupun dibantu dengan guru lesnya, untuk penulisan memang mereka selalu menulis sendiri, tetapi saat guru menanyakan kepada siswa "siapa yang tugasnya dibantu orang tua? dan siapa yang tugasnya dibantu guru les?" dan siswa dapat mengacungkan tangan secara jujur, serta guru juga dapat mengetahui. Saat pembelajaran secara online pun pertanyaan yang diajuka oleh guru sama seperti saat pembelajaran secara offline.

\section{Siswa}

Pada saat siswa mendapatkan tugas sekolah, siswa akan melaksanakan tanggung jawabnya sebagai seorang siswa dalam mengerjakan tugas sekolah sendiri. Tetapi, apabila terdapat tugas yang tidak dipahami oleh siswa, disitulah siswa meminta bantuan orang tuanya. Selama pembelajaran online, siswa pernah terlambat dalam mengumpulkan tugas dengan alasan karena tidak konsentrasi saat mengerjakan tugas dan menyepelekan tugas. Hal ini terdapat kurangnya rasa tanggung jawab siswa dalam pengumpulan tugas. Selama pembelajaran daring, orang tua memberikan rasa tanggung jawab kepada anak, agar dapat mengerjakan tugasnya secara mandiri. Pada saat proses pembelajaran berlangsung, terdapat siswa yang terlambat hadir dalam pembelajaran online dengan alasan bangun kesiangan. Hal ini membuktikan bahwa terdapat siswa kurang tanggung jawab pada saat pembelajaran online. Konsekuensi 
yang didapatkan adalah teguran dari guru, dengan begitu siswa dapat mengingat-ingat teguran tersebut agar tidak mengulanginya lagi.

\section{Orang tua}

Orang tua mendampingi anak saat pembelajaran berlangsung, dikarenakan supaya anak tidak membuka page lain yang bukan materi pembelajaran. Maka dari itu, peran orang tua sangat penting untuk mendampingi siswa pada saat pembelajaran berlangsung. Hatimah (2016) mengatakan bahwa "Pendidikan adalah sebuah tanggung jawab bersama bukan hanya pemerintah, tetapi juga sekolah (guru), dan kelurga (orang tua). Orang tua mendampingi anak saat pembelajaran berlangsung sebagai pengawas, serta orang tua akan mengerti apabila anak mendapatkan tugas dari guru agar tugas dapat dikerjakan dan dikumpulkan tepat waktu. Orang tua membantu anak dalam pembelajaran daring, karena terkadang terdapat siswa yang masih belum faham saat dijelaskan oleh guru, sehingga siswa minta bantuan terhadap orang tuanya, termasuk dalam pengerjakan tugas. Orang tua akan sepenuhnya memberikan tanggung jawab pada anak dalam mengerjakan tugas sekolahnya. Tetapi, terdapat orang tua yang selalu membantu anak dalam mengerjakan tugas dengan alasan agar tidak ketinggalan pelajaran selanjutnya. Hal ini membuktikan bahwa terdapat orang tua yang membantu anak dalam pengerjakan tugas sehingga anak tidak mengerjakan dengan hasil karya sendiri

\section{KESIMPULAN}

Berdasarkan hasil penelitian penulis di SD Muhammadiyah 26 Surabaya mengenai Upaya Guru Dalam Membentuk Karakter Tanggung Jawab Siswa di Era Pandemi Covid-19. Maka peneliti dapat menyimpulkan sebagai berikut:

Upaya guru dalam membentuk karakter tanggung jawab siswa dapat disimpulkan dengan cara berdoa terlebih dahulu sebelum pembelajaran dimulai, memberikan soal yang ada batas waktu mengerjakan sehingga membuat siswa menjadi lebih disiplin, tanggung jawab dalam pengumpulan tugas, pengecekan kelengkapan tugas-tugas, konsekuensi yang diberikan guru untuk siswa yang tidak mengerjakan tugas, tanggung jawab siswa saat masuk dalam pembelajaran online, serta memberikan teguran terhadap siswa yang tidak mengerjakan tugas dengan hasil karya sendiri. 


\section{DAFTAR PUSTAKA}

Afiani Kunti Dian Ayu, M. N. (2021). Pengembangan Media "MEB"dalam Menumbuhkan Rasa Nasionalis. Jurnal Bidang Pendidikan Dasar, 31.

Arifin, Z. (2012). Penelitian Pendidikan. Bandung: Remaja Rosda Karya.

Aslamiah, A. S. (2015). Strategi Kepemimpinan Kepala Sekolah, Guru, Orang Tua, Dan Masyarakat Dalam Membentuk Karakter Siswa. Cakrawala Pendidikan.

Edi, F. r. (2016). Teori Wawancara Psikodignostik. Yogyakarta: PT Leutika Nuvalitera.

Hatimah, I. (2016). Keterlibatan Keluarga Dalam Kegiatan di Sekolah. Pedajogja : Jurnal Ilmu Pendidikan, 4-5.

Martati, B. (2020). Urgensi Konsep Diri Mahasiswa Dalam Pembelajaran Di Era Pandemi Covid19 Sebagai Upaya Pendidikan Karakter. Aceh: Syiah Kuala University Press.

Oktaria, R. \&. (2020). Pendidikan Anak Dalam Keluarga Sebagai Strategi Pendidikan Anak Usia Dini Saat Pandemi Covid-19. Jurnal Ilmiah PESONA PAUD, 7(1), 41-51.

Peraturan Menteri Pendidikan dan Kebudayaan No. 20 Tahun 2018 Pasal 2 tentang Penguatan Pendidikan karakter (PPK).

Pohan, A. E. (2020). Konsep Pembelajaran Daring Berbasis Pendekatan Ilmiah. Jawa Tengah: CV. Sarnu Untung.

Pratiwi Debby, dkk (2021). Analisis Sikap Tanggung Jawab dalam Pelaksanaan Program Merdeka Belajar di Masa Pandemi COVID-19 Pada Siswa SD. Jurnal Gentala Pendidikan Dasar.

Rukmana, L. (Skripsi 2020). Upaya Guru Dalam Membentuk Karakter Tanggung Jawab Melalui Kegiatan Keagamaan Pada Siswa Kelas IV Madrasah Ibtidaiyah Nurul Ihsan Kota Jambi.

Sobron, dkk (2019). pengaruh daring learning terhadap hasil belajar ipa siswa sekolah dasar. FKIP Universitas Veteran Bangun Nusantara Sukoharjo.

Sugiarto, E. (2015). Menyusun Proposal Penelitian Kualitatif: Skripsi dan Tesis. Yogyakarta: Suaka Media.

Sugiyono. (2008). Metode Penelitian Kuantitatif Kualitatif dan R\&D. Bandung: ALFABETA.

Suprayitno Adi, W. W. (2020). Pendidikan Karakter di Era Milenial. Yogyakarta: Grup Penerbitan CV BUDI UTAMA.

Undang-Undang Republik Indonesia No. 20 Tahun 2003

Yunitasari Ria, U. H. (2020). Pengaruh Pembelajaran Daring terhadap Minat Belajar Siswa pada Masa COVID-19 . EDUKATIF: JURNAL ILMU PENDIDIKAN. 